\title{
Baanbrekers
}

\section{P.B.B. Vosloo - Wetenskaplike en Wateringenieur}

\section{J. Haarhoff}

Departement Siviele en Stedelike Ingenieurswese, Randse Afrikaanse Universiteit, Posbus 524, Aucklandpark, 2006

\section{INLEIDING}

Piet Vosloo was 'n merkwaardige mens wat 'n breë spoor op die Suid-Afrikaanse watergemeenskap gelaat het, en 'n onuitwisbare indruk op vele kollegas, eweknieë en vriende gemaak het. In die hedendaagse tyd waarin die meeste van ons hard moet spook om ' $n$ immer kleiner wordende spesialisgebied baas te raak, moet ons verstom staan oor die gemak waarmee Piet Vosloo tegelykertyd wetenskaplike en ingenieur kon wees, 'n kundige kon wees op beide drinkwater en rioolwater, en met ewe veel gemak groot bydraes tot die navorsing sowel as praktiese ontwerp gemaak het. Hierdie artikel is allermins 'n volledige beskrywing van sy ryk bydrae oor 'n tydperk van 50 jaar. Dit beskryf slegs enkele van sy aktiwiteite wat uit sy nagelate tegniese dokumente en uit bydraes van sy familie en tydgenote saamgestel is. Vir die wat hom geken het - mag dit vele goeie herinneringe terugbring. Vir die ander - laat hierdie besondere lewe en loopbaan ons opnuut inspireer om ons eie beste te lewer!

\section{SY LEWE EN WERK IN 'N NEUTEDOP}

\section{Skool en universiteit}

Pieter Barendse Bosch Vosloo is op 20 Februarie 1912 op Somerset-Oos gebore, as die derde kind van Jan Ernst Vosloo van Oukraal en Susanna Sophia Bosch. Hy was een van twee seuns en vier dogters wat as ' $n$ hegte gesin grootgeword het, en wat almal tot die rype ouderdom van 70 jaar of meer geleef het. Sy eerste agt skooljare bring hy deur in die plaasskooltjie op sy pa se plaas, en gaan daarna na Somerset-Oos en matrikuleer in 1928 as 'n sestienjarige met 'n eersteklas aan Gill-Kollege. Hy skryf daarna in by die Universiteit Kaapstad, waar hy 'n B.Sc.graad (Applied \& Industrial Chemistry) in 1933 verwerf.

\section{Chemiese ontleder}

Hy begin sy loopbaan in April 1934 as 'n chemiese assistent by McLachlan en Lazar (Raadgewende Skeikundiges) in Johannesburg. Nege maande later bedank hy en verhuis na die destydse Noord-Rhodesie (Zambië) waar hy in Desember 1934 as skeikundige by die Roan Antelope Copper Mine in Luanshya in diens tree. Agt maande later trek hy terug Suid-Afrika toe, en werk van Augustus 1935 tot Oktober 1936 as assistent munisipale skeikundige en ontleder by die Stadsraad van Pretoria. Dit het die eerste 30 maande van sy loopbaan as algemene chemiese ontleder afgesluit.

\section{Munisipale amptenaar}

In Oktober 1936 word hy aangestel as munisipale skeikundige en ontleder by die Stadsraad van Springs, wat onder andere die beheer oor die dorp se rioolwatersuiweringsaanlegte insluit. Hierdie verbintenis duur meer as tien jaar. Belangrike mylpale in sy lewe gedurende hierdie termyn is sy deelname aan die stigting van die voorloper van vandag se Waterinstituut van Suidelike Afrika (waarna later weer verwys sal word), sy huwelik in 1940 met Helena (Lena) Catharina Vorster (dogter

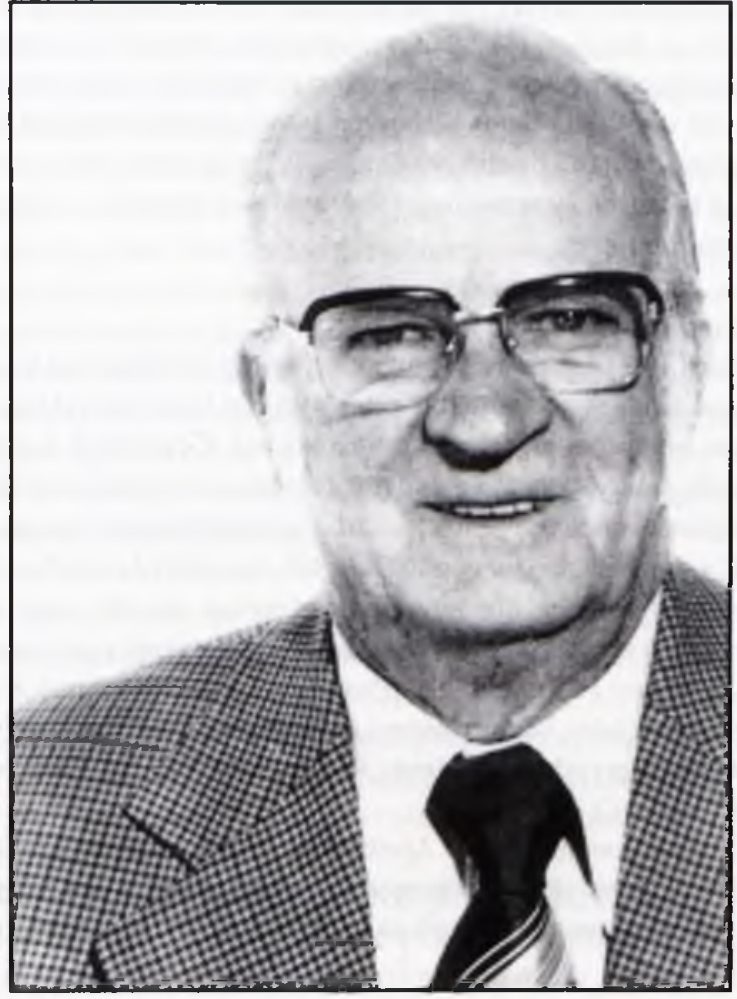

P.B.B. Vosloo

van Johannes Jacobus Vorster van Kestell), en die publikasie van sy eerste drie tegniese referate.

In Augustus 1947 aanvaar hy 'n betrekking as munisipale biochemikus by die Stadsraad van Bloemfontein, en word later bevorder tot munisipale chemiese ingenieur by dieselfde instansie. Hier brei hy sy ervaring uit na drinkwatersuiwering, en is ten nouste gemoeid met die uitbreiding van die suiweringsaanleg by Mazelspoort. Gedurende hierdie tyd is hy 'n kollega van Noel Viljoen, Piet Geustyn en Ken Forsyth, met wie hy later in sy lewe sou saamwerk.

In November 1953 word hy biochemikus vir die Stadsraad en die Afdelingsraad van die Paarl. Hierdie verbintenis duur ' $n$ bietjie meer as ' $n$ jaar. Sy voorganger in die posisie was dr. Gawie Cillié, wat later die Nasionale Instituut van Waternavorsing by die WNNR sou lei, en met wie hy ook verder aan sou saamwerk.

Sy bykans 20 jaar se blootstelling aan munisipale drink- en rioolwatersuiwering, gekoppel met sy fyn waarnemingsvermoë, het ongetwyfeld die grondslag gelê vir die sukses van sy latere rol as raadgewer. Piet Vosloo was veral onder sy jonger kollegas legendaries vir sy onmiddellike begrip van feitlik enige praktiese probleem, en ook vir sy simpatie en begrip vir die probleme van die operateur - eienskappe wat teruggevoer kan word na sy eie harde praktykervaring. 


\section{Navorser}

In Maart 1955 word hy aangestel as senior navorsingsbeampte by die Nasionale Instituut vir Waternavorsing van die WNNR. Dic NIWN was toe nog gevestig op die kampus van die Universiteit van die Witwatersrand. 'n Jaar later, op I April 1956 word hy bevorder tot eerste navorsingsbeample aan dieselide instituut. Teen die einde van 1957, vanaf September tot Desember, onderneem hy en sy vrou Lena 'n uitgebreide studietoer deur Engeland, Holland, Duitsland en Switserland. Hy besoek 45 verskillende aanlegte/instansies met dic hoofsaaklike doel om op hoogte te kom van dic meganismes van bakteriologiese denitrifikasic.

Gedurende hierdie tyd verskyn hy vir die eerste keer in Wie is Wie in Suid-Afrika waar hy angegee word as 'n waterdeskundige. Gedurende 1959 verskyn sy naam ook op die tweede lys van dic WHO Study Group on International Standards for Drinking Water. Hierdic lys bevat 136 toonalangewende name uit 34 lande, en sy spesialisgebied word as maturation - chemi cal studies gelys.

\section{Privaat praktisyn}

In April 1959 betree hy 'n nuwe fase van sy loopbaan toe hy 'n privaat raadgewende praktyk saam met Piet Geustyn en Marius Louw begin onder die naam van Vosloo, Geustyn \& Louw. Hierdic praktyk kan tereg as die voorloper van vandag se multidissiplinêre praktyke genoem word - 'n proseskundige wat saam met 'n siviele ingenieur gepraktisecr het, was destydls ongehoord Moontlik vanweë die nuwigheid daarvan het die praktyk aanvanklik nie goed gevaar nie en die vennootskap is na 'n jaar, op 31 Maart 1960, ontbind. (Piet Geustyn het saam met Ken Forsyth en later Danie Joubert voortgegaan met die praktyk Geustyn Forsyth \& Joubert, wat vandag nog as GFJ Ing voortbestaan.)

Piet Vosloo het vanaf I April 1960, vir die volgende 15 jaar, 'n eenmanpraktyk as raadgewende chemiese ingenieur bedryl' Hy het die fokus van sy werk as volg beskryf (in ' $n$ voorlegging gedateer 6 Junic 1968 aan Namibië se Departement Waterwese)

Ek lê my uitshitlik toe op prosesontwerp, d.w.s. die bepaling van die mees voordelige suiveringsmetode om te gebruik, die groontes en vorm van die verskillende eenhede en die beplamning van die beste uitleg vir die installasie. Sulke werk doen ek gewoonlik in samewerking met die een of ander firma racadgewende siviele ingenieurs, of die ingenieurs op die personeel van die betrokke instansie, hetsy munisipaliteit. staatsdepartement of nywerheid. In dise praktyk wat ek tans. beofen, onderneem ek nie die sumkmele onwerp van voorgestelde water- of rioolswiweringswerke nie. Ek stel bu nie werkstekeninge of tenderdokumente op nie, en hou ook nie toesig oor konstruksiewerk nie. M.a.u., ek onderneem nie die werk wat normalweg dear radgewende siviele ingenieurs aitgevoer word nie. Hierbenewens onderneem ek ook ondersoeke by bestaande water- of rioolwatersaiweringswerke wat nie bevredigend werk nie, om vas to stel wat die oorsake van die onbevredigende werking is, "'ll an te beveel wat gedoen kan word on die mosilikhede op le los.

In hierdie lyd vestig hy hom as een van die voorste walerkenners in die land en doen werk regoor die hele land - munisipaal en industrieel; drinkwater en riool. Daar is haas geen plek in die land waar hy nic gewerk hel nie, soos uil tabel I blyk. In 1975 toe hy reeds 63 jaar oud was, het hy sy praktyk gesluit en as water-en rioolspesialis weer by sy vroeëre vennoot Piet Geustyn se praktyk as deel van GFJ Ing aangesluit. Ilier was hy werksaam tot en met sy dood in 1987

\section{STIGTERSLID EN STEUNPILAAR VAN WISA}

Piet Vosloo was een van die 12 stigterslede van die SuidAfrikaanse tak van die Britse Instituut vir Rioolwatersuiwering. Hierdic geskiedkundige vergadering is gehou op $4 \mathrm{Mei} 1937$ by die Johannesburgse Munisipale Cydna-Laboratorium. Dic

Tabel 1 Plekke waar Piet Vosloo ondersoeke en raadgewende werk gedoen het

\section{DRINKWATER EN RIOOI.WATER}

Badplaas, Balfour, Bethlehem, Blocmfontein, Ermelo, Potchefstroom, Pretoria, Reitz, Rustenburg, Senckal, Standerton, Stillontein, Umkomaas

\section{DRINKWA'TER}

Aliwal-Noord, Balkfontein, Bergrivier-Saldanha, Coligny, Dassenhoek, Ellisras, Frankfort, Glencoe, Groblershoop. Iloopstad. Kaapstad, Kakamas, Karatara, Keimoes, Komatipoort, Kosmos, Koster, Loskop, Malelane, Mandini, Molteno, Morgenson, Naboomspruit, Ngagane, Ngelezana, Nylstroom, Plettenbergbaai, Potgietersrus, Richardsbaai, Sannieshof, Schoemansvilie, Schweizer-Reneke, Sundumbili, Swartruggens, Temba, Vaalkop, Ventersdorp, Virginia, Voëlvlei, Warden, Winburg, Wolmaranstad

\section{RIOOI,WATER EN NYWERHEIDSUITVI,OEISEI.}

Babelegi, Barberton, Benoni, Bethal, Bothaville, Bulawayo, Caledon, Colenso, Darvill, Despatch, Ennerdale, Fauresmith, Francistown, Gatooma, George, Grahamstad, Gwelo, Heidelberg, Johannesburg, Kemptonpark, Kroonstad, Krugersdorp, Lady Grey, Leslie, Lichtenburg, Lobatse, Louis Trichardt, Lydenburg, Mashaba (Zimbabwe), Meyerton, Mpophomeni, Nclola, Newcastle, Nigel, Onderstepoort, Oos-Londen, Oudtshoorn, Phalaborwa, Pictermaritzburg, Pietersburg, Que-Que, Randburg, Randfontein, Rosslyn, Shabani (Zimbabwe), Sishen, Springbok, Strand, Ulundi, Umlazi, Vanderbijlpark, Villiers, Vosloorus, Vredelort, Walvisbaai, Waterval-Boven, Welkom, Witbank

\section{ONIBEKEND}

Bedford, Boksburg, Bosbokrand, Chrissiesmeer, Coalbrook, Delmas, Dimbaza, Graalf-Reinet, Graskop, Greyton, Hallway House, Hartenbos, Hazyview, Heilbron, Hennenman, Jan Kempdorp, Kuruman, Kwadabeka, Kwamhlanga, Kwandengeri, Ladysmith, Letsitele, Lindley, Middelburg KP, Middelburg Mpumalanga, Mitchellsplein, Nelspruit, Oranjeville, Port Shepstone. Riversdale, Salisbury, Silverton, Tzaneen, Upington, Viljoenskroon, Volksrust, Vryburg, Westonaria, Whites 
stigterslede was almal gemoeid mel rioolwatersuiwering alan die Rand en in Pretoria. Die oorspronklike stigtingsdokument word in ligutu 1 aangetoon. Hierdie liggaam het mettertyd ontwikkel tot wat vandag die Waterinstiluut van Suidelike Alrika (WISA) is - 'n trotsc liggaam wat tans sekerlik dic mees invlocdryke verteenwoordiger van waterdeskundiges in Suidelike Alrika is.

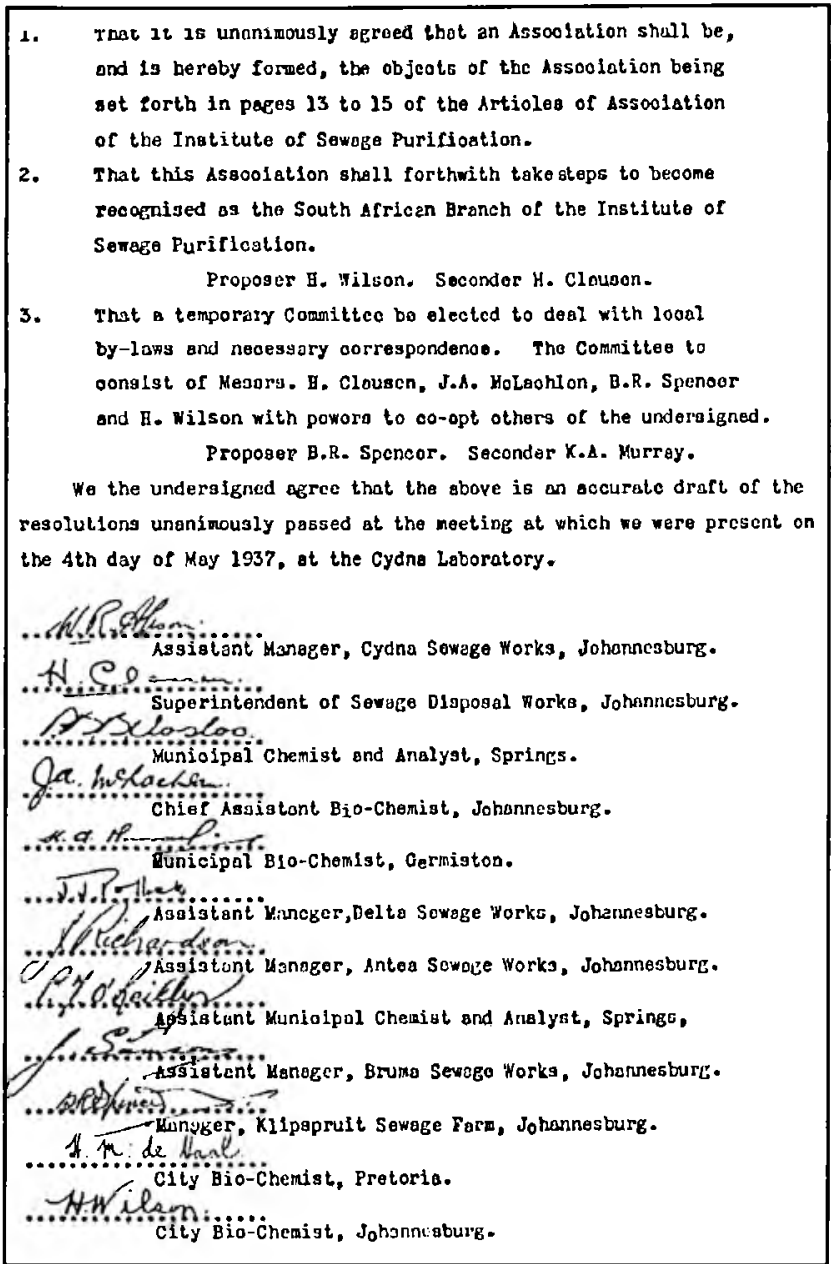

Figuur 1: Afskrif van die oorspronklike resolusie om die voorloper van WISA te stig. P.B.B. Vosloo se handtekening is derde van bo.

Piet Vosloo was later 'n Genoot van die Instituut vir die Bestryding van Waterbesoedeling. Hy het vir meer as 35 jaar in die plaaslike Raad van die Instituut gedien, en was ook vir 'n paar jaar Ere-visepresident van die moederinstituut in Engeland. Hy was ook die eerste persoon wat by twee verskillende geleenthede Voorsitter van die Suid-Afrikaanse tak was. Sy eerste termyn as Voorsitter was 1947/48, dic jaar toc hy vanaf Springs na Blocmfontein verhuis het. Sy tweede termyn was in 1964/65, wat algesluit is toe hy op 18 Februaric sy Voorsittersrede gelewer het. By hierdic geleentheid het hy gepraat oor Effluent Standards and the Protection of our Water Resources.

Hy was ook lid van 'n aantal ander professionele verenigings, onder andere lid van die Suid-Afrikaanse Chemiese Instituut, Fakulteitslid van die SA Akademic vir Wetenskap en Kuns, en Affiliaat van die SA Instituut van Sivicle Ingenicurs. Alhoewel hy geen ingenieursgraad verwerl het nie, doen hy formeel in Februaric 1969 aansock om lidmatskap van die SA Instituut vir Chemiese Ingenicurs, wat feitlik onmiddellik goedgekcur word - hy word later tot Genool verhef. Hy word ook in Julic 1969 as professionele ingenieur geregistrecr.
KAMPVEGTER VIR AFRIKAANSE VAKTAAL,

Piet Vosloo het 'n besondere verbale en skriftelike uitdrukkingsvermoe gehad en het 'n akticwe rol gespeel om Alrikanse vaktaal binne wateringenieurswese te skep. Ily het deelgeneem aan die baanbrekerpublikasic Water- en Rioolwaterterme valn die SA Akademie se Vaktaalburo. In 1966 is 'n uitgebreide debat gevoer oor die moontlikheid om die term rioolvail in plaks van rioolwater te verkies. Piet Vosloo het namens die Instituut 'n breedvoerige en oortuigende betoog ten gunste van rioolwater. aan die Direkteur van dic Vaktaalburo (Prot. Van Rensburg) gerig, en aanbeveel dal dic term rioolvail nie eers as alternaticl aanvaar word nic - wat in 1967 in 'n hersiene uitgawe gedoen is. Twintig jalar later, in 1986, het die Suid-Alrikanse Buro van Standaarde (SABS) weer dic term riool'yil uil die bloute in die Statskoerant gebruik, wat tot 'n hefige briefwisseling tussen hom en die SABS gelei het.

In 1976, in 'n ander briefwisseling (wat behoue gebly he1), met die leksikograal' dr. F.J. Snijman het 'n alantal ander terme te berde gekom. Piet Vosloo het gemotiveer hoekom shuelge met slyk eerder as s/ik vertalal moet word (omdal slik 'n spesilieke tegniese begrip in die grondkunde geword hel), en hoekom hy intussen sludge blanket sedimentation met s/yklarag/illrasie vertaal cerder as om die term kombers in die vertaling te gebruik. Sy geneigdheid om alles (nie net vaktalal nie!) tot op die been oop te vlek en te verstaan, word deur die volgende alanhaling uit hicrdic bricl geillustreer:

Tot na 1964 het ek konsekwent geweier om die woord flokkulasie as allernatief vir witvlokking te gebruik, anangesien dact in die proses wokke gevorm word en nie flokke nie! Sederdien het ek my latat oorruig deur die argament dar albei vorms van dieselfde stamwoord afkomstig is, die een via die Romaanse tale, en die ander via die Germaranse tale.

\section{SUIWER EN PRESIESE KOMMUNIKATOR}

Soos met sy aandrang op presiese en keurige Afrikiannse vaktaal, het Piet Vosloo homself onderskei met besonder gedetailleerde en ondubbelsinnige tegniese kommunikasic.

Sy aandrang op ondubbelsinnige terminologic en melodes blyk reeds in 'n vroeë stadium toc hy in 1947 in ' $n$ publikasic voorbrand maak vir' 'n beter gestandaardisecrde toets vir' dic OA-toets (dic "Oxygen Absorbed"-toets walarmee die sterkte van rioolwater gemeet word). In 1970 neem hy weer deel than 'n debat oor dieselfde onderwerp, toe die terminologie van $O A$ na $P V$ ("Permanganate Value") verander is. (Hierdic debal, terloops, het hy ondanks sy helder en oortuigende argumente daarteen, verloor omdat dic moederliggaam in Engeland toe reeds op $P V$ besluit het.)

Piet Vosloo het, ondanks die geweldige reikwydte valn die werk wat hy gedoen het en sy unieke vermoë om tot die kern van 'n saak deur te dring, nie 'n besondere groot publikasicrekord nagelaat nic. Sy formecl gepublisecrde relerate word in tabel 2 aangedui. Van sy beste werk het hy egter in die vorm van verslac aan kliënte opgeskryl, of in die vorm van kommentaar op ander se relerate of aanbiedings, waarna later verder verwys sal word. Hy was ook 'n gewilde en gesogte spreker by konferensies en opvoedkundige instansies. Oor dic jare het hy lesings angebied vir SAISI, WISA. Universileit Pretoria (voor-sowel as nagraads), Universiteit vin Stellenbosch (nagraads), Pretoria Technikon, en by konferensies en maandvergaderings van WISA

'n Verdere cienskap wat samanhang met sy kommenikasicvermoë, was sy hedrewenheid om mocilike begrippe met ecnvoudige alledaagse analoê te verduidelik. Hy illustreer byvoorbeeld die begrip van eerste-orde-afname van lekale 
baktericę in 'n oksidasiedam. gegee deur die differensialalvergelyking $\mathrm{dN} / \mathrm{dt}=-\mathrm{kN}$, as votg:

We can sherefore compare them to a very large number of assorred males left on an istand in the middle of the Pacific Ocean, will enough of the necessities of life to enable them to continue their existence. As they cannot multiply, their number will gradually decrease. Some will die of old age, some of disease, some may fall prey to wild animals, and some may even commit suicide, but one thing we can say with a great deal of certainty, and that is that, at any stage in the proceedings, the number of deaths per month will be proportional to the number of survivors at that stage. This excludes the occurrence of a smallpox epideninic, of course, which could have the same effect on the island dwellers as a good shot of chlorine would have on the faecal organisms in the pond.

\section{SY TEGNIESE BYDRAES EN BENADERING}

'n Fundamentele ingenieursbenadering tot watersuiwering Pict Vosloo se onderskeidende kenmerke was eerstens sy vermoë om praktiese probleme te reduseer na fundamentele, teoreties korrekte oorwegings, en lweedens sy atundrang om mel dic lynste detail van 'n probleem vertroud te wees. Onderliggend hichan was sy besel dall die sukses van suiweringsprosesse tell nouste alhanklik is van behoorlike chemiese dosering en voorbehandeling, en van die hidrouliese vlocipaltrone deur die prosesreaktore. Een van die eerste verduidelikings wal die skrywer, en vele ander kollegas, by hom gekry het. wals 'n duidelike uiteenselling van die verskillende vloeipatrone deur reaklors - propvloei leenoor volledig vermengde vloci. en sy heftige voorkeur aan propvloei vir chemiese vermenging en llokkulasic! Hy was 'n vurige voorstander van hidrouliese kronkelkanale vir llokkulasie. So vroeg as 1964 (lank voordal bogenoemde begrippe die wye neerslag in die praktyk gekry

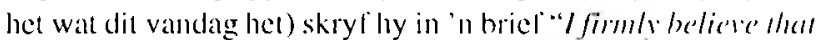
floc channels offer the only satisfactory method of flocen-

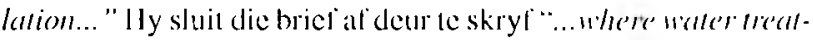
ment plants failed to operate satisfactorily, the main canse of the trouble proved to be incadequate flocintation..."

Grool klem is gele op akkurate hidrouliese berekenings vall vloeisnelhede en energieverliese, en menige siviele ingenieur (wat veronderstel is om dic kenners op die gebied te wees!) moes op sy neus kyk wanneer Piet Vosloo met sy alomleen-

Tabel 2 Formeel gepubliseerde publikasielys van P.B.B. Vosloo

I. Vosloo, P.B.B., O'Reilly, P.T. (1945). The Elfect of Artificial Ventilalion on the Treatment of Sewage by Biological Filters, Jour \& Proc Institule of Sewage Purification, part 2, p. 160-16.3

2. Vosloo. P.B.B. (1947). Some Experiments on Rapid Sand Filtration of Sewage Works Efrluent without Coangulants, Iom de Proc Institute of Sewage Parification, part I, p. 204-209.

3. Vosloo. P.B.B. (July 1947). Proposal for a more rigid Standardisation of the "Oxygen Absorbed from Permanganale" Test. Public Health, p. $11-18$.

4. Vosloo, P.B.B. (November 1949). Die Belang van die Gesondheidsbeample by die Opruiming van Rioolslik, Volksgesondheid, p. 340-347

5. Vosloo, P.B.B. (Januarie 1954). Probleme in verband met Verkoclingswater by 'n Kragsentrale, Tegnikon, p. 178-190). 197-199.

6. Vosloo. P.B.B. (Junie 1956). Die Suiwering van Rioolwaler en Nywerheidsafloopwater met betrekking lor die Voorkoming van Besoedeling, Volksgesondheid, p. 31-42. Was eers as NIWN-verslag beskikbalar - voorgeda by dic $1.3 \mathrm{de}$ Gesondheidskongres in Pretoria in 1955.

7. Gien, I., Vosloo, P.B.B., Stander, G.J. (January 1957). Digestion of Night Soil by an Elutriation Techniçue, Public //ealih/. p. $31-33,45$.

8. Vosloo, P.B.B., Finsen, P.O. (July/August 1957). 'The Application of the Activated Sludge Process to the lunther Purificattion of Biological Filter Effluent, The Water and Waste Treatment Jotumal, p. 348-352.

9. Vosloo, P.B.B., Sampson, D. (March 1958). The Nephelometric Method for the Determination of Sulphate in Water. SA Ind Chem, p. 48-50.

10. Stander, G.J., Vosloo, P.B.B. (January 1960). Chemical and Biological Aspects of Raw Water Supply and Purilication. Institution of Mun Engineers, Ammal Joumal, vol. 1, number 13.

11. Vosloo, P.B.B., Denysschen, J.H. (1965). Die Suiwering van Water vir Huishoudelike Gebruik. Water (SA Akademie vir Welenskap en Kuns).

12. Vosloo, P.B.B. (1970). Some Factors relating to the Design of Activated Sludge Plants, Water Pollution Control, vol. 69. number 5, p. 486-495.

13. Vosloo, P.B.B. (1973). Oxygen Requirements in the Activated Sludge Process, Water Pollution Control, vol. 72 , number 2. p. $209-212$

14. Vosloo, P.B.B. (1975). Setlement and Sludge Return in Activaled Sludge Type Package Plants, Water Pollution Comtrol. vol. 74, number 2, p. 197-198.

15. Vosloo, P.B.B. (1978). Design of Drying Beds for Surplus Activated Sludge, Water Pollution Control, vol. 77, number 1. p. $71-74$.

16. Vosloo, P.B.B., Langenegger, O. (Jan./Feb. 1978). Richards Bay Mzingazi Water Purification Works, IMIESA. vol. 9, number 1, p. 71-73.

17. Plant, G.W., Vosloo, P.B.B. (1984). The Failure of a Soil Blanket Lining caused by the Action of Bacteria, Proceedings of an International Conference on Case Histories in Geotechmical Engineering, Editor Shamsher Prakash. held May 6-II. St. Louis, Missouri, p. 689-693.

18. Vosloo, P.B.B., Williams, P.G., Rademan, R.G. (1986). Pilot and Full-Scale Investigations on the Use of Combined Dissolved-Air Flotation and Filtration (DAFF) for Water Trealment, Wenter Pollution Control, vol. ?, number ?. p. 114-121 
woordige Handbook of Hydraulics vall die skrywer King 'n berekening verbeter of aangepas hel. Tipies van die sorg waarmee hy die hidroulika in ag geneem hel, is 'I aanhal ing uit 'n lesing oor sandfiltrasie wat hy in 1969 by die UP' se Somerstiool gelewer het:

Special provision has to be made for even distribution of the washwater ander the filter media. One cannot merely pump) the washwater into a laver of coarse media tander the sand on the assumption that it will spread to all parts of the bed and come up uniformly through the sand. In actual fact, if the washruater is capable of free movement in a laver of coarse media tunder the sand, the last thing it will wamt to do is to spread itself evenly throughout this laver and come up aniformly through the sand. It will do exactly the opposite. i.e. it will converge on one or two points where it will pass up, at lery high velocity, through a relatively small area of the bed, forming a "pipe" through the sand...

In 'n ander geval, terwyl hy 'n konferensie in 1974 in die destydse Salisbury oor kleinskaalse pasklatir rioolatanlegte toespreek, gebruik hy bykans twee bladsye van sy geskrewe releraat om in presiese delail te verduidelik hockom rioolslyk in 'n spesifieke geval mie spontaan as gevolg van klein digtheidsverskille deur' 'n gleul' in dic reaktormuur sal vloci nic!

'n Ander gebied waaroor hy besonder hesorg was, was dal chemikalieë uiters presies en egalig in water gedosecr moes word. In 'n korl essay skryf hy lwee jaar' voor sy dood in 1987:

... the chemical should be completely dispersed in the raw water in a fraction of a second. If the water flows at a constant rate (which is a sime aua non for good performance), the chemical must also be added to it at a constamt rate. A pulsating chemical dose, such as that delivered by a positive displacement dosing pamp) with adjustable stroke is canite anaccepable, anless the pulsations are damped ont completely...

Tydens sy lesingrecks aim dic Universiteit van Stellenbosch in 1980/81. het hy selfs na die onoordeclkundige gebruik van chemiese pulspompies verwys as: "... an invention of the devil"!

\section{Oor wiskundige modellering}

Hy hel 'n kritiese en praktiese siening oor die rol valn wiskundige modelle in die ingenieurswese gehad. Dal hy self gerecld die wiskunde met groot bedrewenheid ingespan het om probleme op te los, ly geen twyfel nie - in sy notas kry ons 'n voorbeeld walar hy die energie van 'n waterkolom wat in 'n konusvormige tenk roteer met ingewikkelde integralaltekening vanuit eerste beginsels algelei het. Maar hy sou nooit wiskunde gebruik on 'n oplossing te vind wat hy nie ecrs intuïticf vir homself kon uitredeneer nie. 'n Voorbeeld van sy skeptisisme leenoor "blinde" wiskunde blyk byvoorbeeld uit 'n bespreking wal hy in die sestigerjare op dic baanbrekerswerk van Marais en Shaw lewer (wat 'n omvangryke wiskundige model vir die werking vall oksidasiedamme opgesiel het):

... I got the impression that the atuthors were juggling with mathematical expressions and proofs for the sheer joy of it, if not actually for the express purpose of making things more difficull for us lesser morfals! It came as a greal surprise and a litule bit of a shock to me to discover that the lumble oxidation pond - a mere hollow in the surface of the carth, filled with polluted water and exposed to God's sim, wind and air, could be the object of such eradite mathematical reasoning. We have certainly foumd wo young Somb africalls who cen outdo the Americans at epolving imbricale mathematical formulae for expressing the mechamisms of biological processes!

"n Rukkie later verander dic joviale tram na skerjer kritiek:

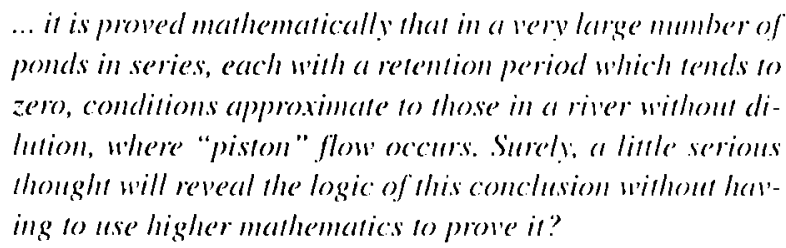

Piet Vosloo was nic bang om standpunt in te neem, hoe ongewild ookal, lecnoor alannames wat hy nie mel sy eie begrip van 'n proses kon versoen nie. Een so 'n atunname (wat sleeds universeel gebruik word) is dat die organiese materiaal teen ecrste-orde $(\mathrm{dC} / \mathrm{dt}=-k \mathrm{C})$ in 'n biologiese reaktor verval (hy verwys ma eerste-orde-verval as die "Law' of Mass Action"). In 'n lang geskrewe beloog (wat 'n kragtoer in logiese redenasie is. maal wat te lank is om hier herhaal te word) bewys hy dat 'n substralal leen 'n konstanle lempo deur mikro-organismes gemelaboliseer sal word. Hy wys vervolgens op drie redes hockom dit mag vorkem asof die tempo afneem, matr glo onwrikbatr dal dit verkecrl is om wiskunde vir modellering te gebruik wall nic met die fundamentele meganismes versoenbalar is nie. Hy sluil sy betoog al met:

I have gone to some pains to show that it is probably anite correct to say that many biochemical reactions stow down as they proceed. This...cammot be taken to mean that the Law of Mass Acrion necessarily applies to such reactions. Where such reactions therefore do appear on obey the Law of Mass Action, it is my humble opinion that this is murely co-incidental, and nor because there is any rational scientific basis for it.

\section{Waardige humor}

Gekoppel met skerp kritick, was daar dikwels ook 'n walardigo humor. Hy sluit sy kritick in 1965 on 'n voorgestelde nuwe suiweringsproses as volg af:

... but I am afraid it may not be practicable. It must be admitted that the thought of $\$ 800$ giant disc's, 20ft in diame'te'; rotating ponderous/s; and suspended in row's apon row's of lamks, 12fl wide and 12fi deep, all to purify one million gallons of sented sewage per day, does call forth bisions of $\mathrm{M}$ : Heath Robinson.

In ligte luim merk hy in 1971 tydens 'n bespreking op:

I was called in on the process design, so that I had a share in the conception of the scheme. This is, of contse. the most interesting part of the job - after all, no less a man thrm President Pompidon himself has recomly pointed out that conception is always more agreable than child birth!

\section{Nuwe prosesse}

Behalwe sy vermoë om te ontleed en te verstam. het hy ook groot bydraes gemalak tol die verbetering en optimalisering van prosesse. Hy het ook nie gehuiwer om nuwe prosesse te ontwikkel en te beproel nic. Hy was die balanbreker wall vir dic eerste keer in Suicl-Alrika die prosesse van opgelostelugllotlasic met littrasie in 'n enkele reaktor gekombineer het. Itierdie proses 
is eers getoels in 1983 by Richardsbaai, walaruit een van sy laaste publikasies gevloei het. Na aanleiding hiervan het hy die proses verder ontwikkel soos dit in 1988 by die Rietvlei-aanleg naby Pretoria in bedryf gestel is - 'n proses wal vandag nog steeds met groot welslac werk en besockers vanoor die hele wêreld getrek het.

Op die gebied van rioolwatersuiwering was sy bydraes ook noemenswaardig. Hy he jare spandecr om die meganiese probleme by geaktivecrde slykaanlegte na te speur en op te los, soos uit 'n aantal publikasies blyk. Een van sy unieke bydraes tot die veld van rioolsuiwering was die ontwikkeling van die sogenaande verouderingsrivier, 'n stelsel wat hy gebruik het om die helderheid van riool water te verbeter wat deur biologiese sypelbeddens gesuiwer is. Hy hel die proses in die vroeë 1970's reeds op 'n paar plekke loegepas (Umlazi, Despatch, Onderstepoort, Malclane, Ermelo en Standerton). Dit het kortliks beleken dat dic gesuiwerde water nie in 'n sogenaamde verouderingsdam gestort word wat deur die wind vermeng kan word nie, maar in 'n kanaal waar die water voortdurend vorentoc beweeg, en wat dus tot benaderde propvloci lei (let op die chemiese reaktorteorie!). Hy skryl dic sukses van die stelsel toe aan die volgende (in 'n brief aan W.M. Malan in 1973):

\begin{abstract}
Besoedelde water wat in 'In nattarlike stroom met 'n taamlike reëlmatige dwarssnit vloei, ontwikkel normalweg nie die massiewe hoeveelhede eensellige alge wat dieselfde water in 'n dam son ontwikkel nie. Instede hiervan vind 'n mens. groot hoveethede string-alge wat an die bodem en die kante van die stroom vasgeheg is, terwyl die water wat dardeur vloei, betreklik skoon bly. Hiervoor kan ons slegs een uitleg vind, natamlik dat die eensellige alge taamlik stadig anteel. Water wat in 'n rivier sonder poele vloei, word nooit aan massiewe inenting met eensellige alge blootgestel nie en vertoef nie lank genoeg ... in die rivier om hierdie alge die geleentheid te gee om vanself te vermeerder tot die groot getalle wat nodig is om dit groen te kleur. In stede hiervan ontwikkel daar string-alge, wat nie saam met die water wegdryf nie, maar hulle aan die kante vasheg en dus baie tyd het om hulle daar te vestig en behoorlik te ontwikkel. ongeag van die dearvloeityd van die water self. Hierdie string-alge het 'n aanmerklike suiweringseffek ...
\end{abstract}

\section{Oor die omgewing}

Piet Vosloo het ook sy aandag gegee aan die wyer balans tussen mens en natuur. In dic konteks van vandag se steeds toenemende omgewingsbewustheid, mag van sy denkrigtings dalk tiitgediend en selfs verstok klink, maar dic punt is dat hy ellike dekades gelede reeds die insig gehad het om omgewingsimpakte te probeer kwantifiseer, om sodoende by 'n gebalanseerde en motivecrbare standpunt uit te kom. Reeds in die sestigerjare het hy replick gelewer op 'n studic na dic moontlike besoedeling van Valsbaai (deur Atkins en Stecre):

...while the facilities provided by nature for the parification of wastes should by no means be abused, there was nothing wrong whatsoever in exploiting these facilities to the full. This would benefit not only the particular industry involved, but in the overall picture, also the economy of the country as a whole.

In 1981 ontwikkel hy hierdie standpunt in veel groter detail in 'n memorandum oor dic voorgestelde secriool by Richardsbaai, na alanleiding van 'n konsepregulasic wat dic Munisipaliteit sou verplig om eers die rioolwater te hesink voorlat dit in die see gestort kan word. Hy was heftig hierteen gekant, maar het eers in ses bladsye baic duidelik die verwagle besocdeling in perspekticl geplaas, voordat hy 'n verslapping van dic regulasic bepleit het. Hy begin met:

This is not a plea for anrestricted pollution, bat rather fon some sense of perspective in the methods we employ for its control and abatement. The criterion for any restriction on the discharge of an effluent should not be whether it is capetble of being achieved, bul raher whether it is necossisary ander the particular circumstances. In other nords, do not insist on the maximum that is possible. but rather on the minimum that is necessary.

Nal 'n beraming van die besoedelingsvrag wal verwag word, haal hy 'n aantal studies aan wat op die Suid-Kaliforniese kus uitgevoer is. Ily sluit sy betoog all:

Los Angeles County and Los Angeles Cirvi, oner a length of coast line of no more than $40 \mathrm{~km}$, discherge betwe's the'm... sewage to sea with a population equivalem of aboul 8 million people ... The damage has nor been particularly serious, and what damage there has been, was confined to an extremely small area... The wastes to be discharged by Richards Bay pale into insignificance compared to those of Los Angeles. What earthly danger is the re then that the damage they could canse would be so serious as to justifiv the stringent restrictions...?

Sy pleidooi dat die vereiste van besinking laat vala moel word. en eerder vervang moet word met die vereiste dat die riool deur 'n kerwerstasic lyngekap moet word om te verhoed dal drywende materiaal dic kus bereik, is later aunvaar.

\section{AFSLUITING}

Suid-Alrika het in die waterveld, soos in so baie ander wetenskaplike gebiede, meer as sy kwota fenomenale ingenieurs en denkers opgelewer. Pieter Barendse Boseh Vosloo was een van dic grotes. Hicrdic oorsig belig maar slegs enkele hocke van hierdie talentvolle en veelsydige mens. Die skrywer he hom slegs agt jaar voor sy dood leer ken, en slegs sowall drie jala saam in diesellde kantoor gewerk. Sy reuse-inlellek, en ongebreidelde geesdrif vir alles wat hy alangepak het, het "n onuitwisbare invloed op almal rondom hom gelatat. Dit is die doel hiervan om iels van hierdie glans en voorreg, hoe karig dil ookal beskryf is, na andere te weckiats.

Piet Vosloo was enduit fiks, gesond en helder valn verstand. Hy het 'n vol, akticwe en bevredigende lewe gelei tol 'I clag voor sy dood op 11 Oklober 1987, toe hy aan 'n hallianval beswyk het. Hy het sy vrou, een dogter, I wee seuns en nege kleinkinders nagelaat.

\section{ERKENNINGS}

Die raadgewende ingenieurs GFJ Ing. (voorheen Geustyn Forsyth \& Joubert) het Piet Vosloo se uilgebreide versameling tegniese korrespondensic (altesalam vier groot liassecrkabinette) sedert sy dood in 1987 in hulle argief bewaar. Hulle het ook die aanmoediging en administratiewe hulp verskalf om hierdic kabinelte deur te werk en te orden. en om hicrdic arlikel persklaar te kry. Mnre. Ken Forsyth. Willic Malan en mev. Nina van den Heever (dogter) het die konsepdokument hersien en aangevul. 